\title{
SHEAR LAG EFFECT IN THE NUMERICAL EXPERIMENT
}

\author{
M. SZUMIGALA ${ }^{1}$, K. CIESIELCZYK ${ }^{2}$
}

The standard PN-EN 1993-1-5: 2008 (Eurocode 3) compared with the standard (PN-B-03200: 1990) used previously in Poland, introduces extended rules referring to the computations of the bearing capacity of the plated structural elements including the shear lag effect. The stress distribution in the width flanges is variable. Therefore in the case of the beam with the shear lag effect cannot be calculated by the classic beam theory.

In this article a comparison of the results of the calculations of forces distribution, stresses and displacement according to the rule presented in PN-EN 1993 and results of the numerical computations for 3D model (using finite element method) is presented. The elastic shear lag effects, the elastic shear lag effects including effects of the plate buckling and the elastic-plastic shear lag effects including the local instabilities were analysed. The calculations were performed for beams with a small and a large span and an influence of stiffeners was analysed.

Keywords: Eurocode 3, numerical analysis, plated structural elements, shear lag effect

\section{INTRODUCTION}

According to the classic beam theory the value of the normal stresses in the point with coordinates $(x, y)$ is determined using the following formula:

$$
\sigma_{x}=\frac{M_{y}}{I_{y}} z
$$

\footnotetext{
${ }^{1}$ DSc., PhD., Prof. Poznan University of Technology, Faculty of Civil Engineering and Environmental Engineering, Piotrowo 5, 60-965 Poznań, Poland, e-mail: maciej.szumigala@put.poznan.pl

${ }^{2}$ MSc, Poznan University of Technology, Faculty of Civil Engineering and Environmental Engineering, Piotrowo 5, 60-965 Poznań, Poland, e-mail: katarzyna.ciesielczyk@put.poznan.pl
} 
This means that the distribution of the stresses in the y direction is constant on the entire width of the flange. However, when the flange of the beam becomes wider, this assumption becomes incorrect. The non-linear stress distribution occurs on the width of the flange in beams which have the width of the flanges larger than their length. This phenomenon is called the shear lag effect. The highest value of the stress in the flange occurs in the points situated directly above the web. The farther the point of the flange is away from the web, the value of the stress decreases (Fig. 1).

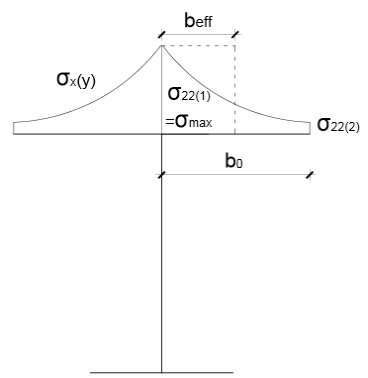

Fig. 1. Stress distribution in width flange [8]

Because of this phenomenon, in case of the beams with width flanges analysis, calculations cannot be performed according to the elementary theory of bending. Reducing the width of the flange to the effective width is assumed to be the simplest of the methods proposed in some design standards (also in Eurocode 3) [2].

\section{IDEA IF THE EFFECTIVE WIDTH}

The concept of the effective width was presented for the first time in 1924 by Theodore von Kármán [6] and it was related with effective width in relation to the thin-walled cross sections. Due to the simplicity of the proposed solution by Kármán it has been widely adopted to determine stress distribution due to shear lag in the steel structures.

It is assumed that the effective width is determined by the following formula:

$$
b_{\text {eff }}=\frac{1}{\sigma_{x, \max }} \int_{0}^{b_{0}} \sigma_{x}(y) d y
$$


where: $b_{\text {eff }}-$ the effective width, $\sigma_{x, \max }-$ the maximum value of the normal stress in the flange caused by of shear lag effect, $\sigma_{\mathrm{x}}(\mathrm{y})$ - the normal stress in the flange, $\mathrm{b}_{0}$ - the width of the flange, according to the Fig. 1.

In order to study the influence on the stress distribution of the shear lag effect the effective width factor $\beta$ should be designated. The $\beta$ ratio expresses the relation between the effective width and the real width [4]:

$$
\beta=\frac{b_{e f f}}{b_{0}}
$$

If the stress distribution in the flange is almost constant (shear lag effect is very small), the value of $\beta$ ratio will be close to one. The bigger change of the stress distribution causes bigger influence of the shear lag effect (the of $\beta$ ratio decreases). In the engineering practice often the stress distribution in the flange $\sigma_{x}(y)$ is unknown which should be determined. In this case, the effective width cannot be determined using the 2.1 formula. The effective width is determined by converting the 2.2 formula to:

$$
b_{\text {eff }}=\beta b_{0} .
$$

State of strains in the plates is determined by the following formula [5]:

$$
\frac{\partial^{2} \varepsilon_{x}}{\partial y^{2}}-\frac{\partial^{2} \gamma}{\partial x \partial y}+\frac{\partial^{2} \varepsilon_{y}}{\partial x^{2}}=0
$$

where: $\varepsilon_{\mathrm{x}}$-the strain in the longitudinal direction, $\varepsilon_{\mathrm{y}}-$ the strain in the transverse direction, $\gamma$ - the shear strain.

In order to simplify the equation, it is assumed that the transverse stiffness is infinity (the strain in the transverse direction is equal to zero).

$$
\frac{\partial \varepsilon_{x}}{\partial y}-\frac{\partial \gamma}{\partial x}=0
$$


This assumption leads to the warping function $w_{s}$, which formula was presented by Johansson $\mathrm{B}$ et al. [3]. The final shape of the warping function is presented in the Figure 2. Strains are defined by the equations:

$$
\begin{gathered}
\varepsilon_{x}=-w_{s} \frac{\partial^{2} \theta}{\partial x^{2}} \\
\gamma=-\frac{\partial w_{s}}{\partial y} \frac{\partial \theta}{\partial x}
\end{gathered}
$$

where: $\theta$ - the angle of rotation.

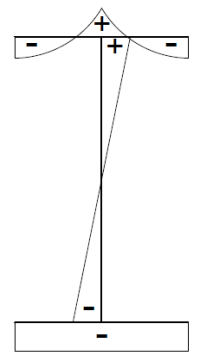

(1)

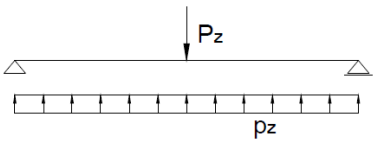

(II)

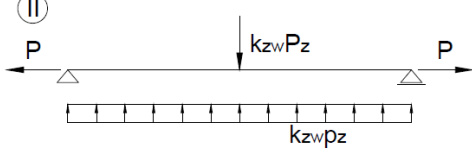

II:

$$
\text { (2.8) } \quad M_{y}{ }^{\prime}=E I_{y}{ }^{\prime} \frac{\partial^{2} \theta}{\partial x^{2}}+P \theta
$$

where:

$$
\begin{aligned}
& I_{y}{ }^{\prime}=\int w_{s}{ }^{2} d A, \\
& P=G \int\left(\frac{\partial w^{\prime}}{\partial y}\right)^{2} d A .
\end{aligned}
$$

I: Hooke's law for bending:

$$
M_{y}=\frac{E I_{y}}{\rho}
$$

where:

E - the Young's modulus, $I_{y}$ - the moment of inertia with respect to the $y$ axis: $I_{y}=\int z^{2} d A, \mathrm{~A}-$ the plane area, $\frac{1}{\rho}-$ the curvature: $\frac{1}{\rho}=w^{\prime \prime}$, $\mathrm{w}-$ the transverse displacement.

Fig. 2. The final shape of the warping function [3]

In the next step the normal stress of the bending moment $M_{y}$ (for the real width of the flange) and $M_{y}$ ' should be determined. The final stress distribution in width flange is formed by adding together these two stress values. 


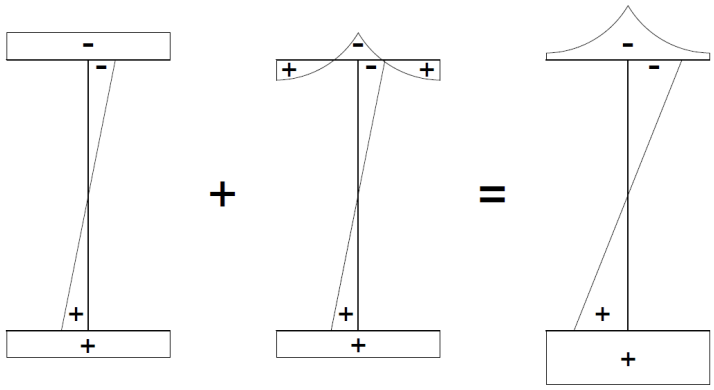

Fig. 3. Stress distribution with the shear lag effect [3]

The value of the effective width factor $\beta$ depends on the shape of the bending moment diagram. To determine the $\beta$ ratio formula the continuous beam should be divided into series of simple beams (the dividing points are these where the bending moment is zero). Then, depending on the shape of the bending moment at each of the beam parts the shape ratio $\psi$ should be determined, by [3]:

$$
\psi=4 \frac{\Delta M}{M_{\max }}
$$

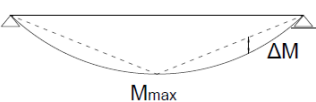

$$
\Delta M=-\frac{M_{\max }}{4}->\psi=-1
$$

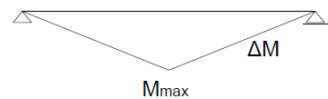

$\Delta M=0->\psi=0$

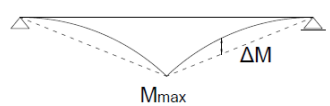

$\Delta M=\frac{M_{\max }}{4}->\psi=1$

Fig. 4. The shape ratio [5].

After solving the equation (2.4) and introducing some simplification (by [3]) the $\beta$ ratio formula can be derived as follows:

$$
\beta=\frac{1}{1+4(1+\psi) \frac{\alpha_{0} b_{0}}{L_{e}}+3,2(1-\psi)\left(\frac{\alpha_{0} b_{0}}{L_{e}}\right)^{2}}
$$

where: $L_{e}-$ the effective width (the distance between adjacent points of zero bending moment), $\alpha_{0}-$ the ratio depending on the cross section of the all longitudinal stiffeners, $\Sigma \mathrm{A}_{\mathrm{sl}}-$ the area of all longitudinal stiffeners, $t$ - the thickness of the flange. 

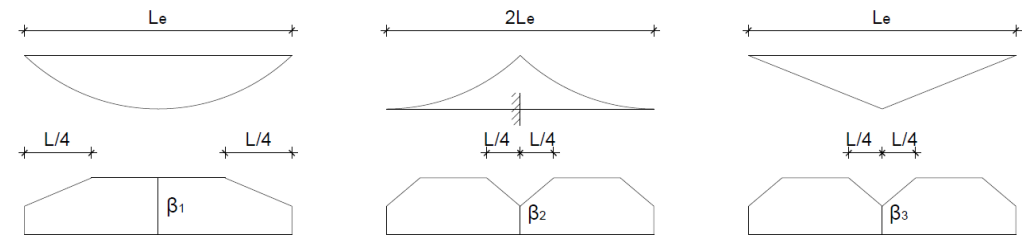

$$
\beta_{1}=\frac{1}{1+6,4\left(\frac{\alpha_{0} b_{0}}{L}\right)^{2}}
$$

$$
\beta_{2}=\frac{1}{1+6 \frac{\alpha_{0} b_{0}}{L}+1,6\left(\frac{\alpha_{0} b_{0}}{L}\right)^{2}}
$$

$$
\beta_{3}=\frac{1}{1+4 \frac{\alpha_{0} b_{0}}{L}+3,2\left(\frac{\alpha_{0} b_{0}}{L}\right)^{2}}
$$

Fig. 5. Effective width factor depending on the distribution of the bending moment [3]

The standard [8] includes ready formulas on the effective width factor $\beta$ depending on the bending area.

\section{Finite Element MODEL}

In order to determine the forces and stress distribution, numerical computations in the Abaqus $[10,11]$ program were performed. The plated structural element was modelled as three - dimensional shell element. The steel beam was replaced by finite elements S4R - four - node shell elements with reduced integration (smaller number of Gauss points).

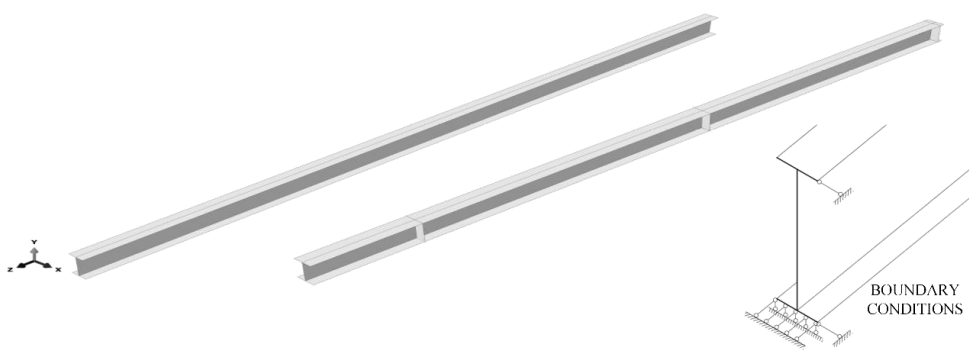

Fig. 6. Shell model of the plated structural element without and with the stiffeners

The loads were defined as distributed loads and applied to the entire length and width of the flange. The following two steel models were used in computations:

- Elastic model:

- the Young's modulus:

$$
\begin{aligned}
& E=21 \cdot 10^{10} \mathrm{~Pa}, \\
& v=0,3 .
\end{aligned}
$$$$
\text { - the Poisson's ratio: }
$$ 
- $\quad$ Elastic - plastic model with minimal, linear strain hardening.

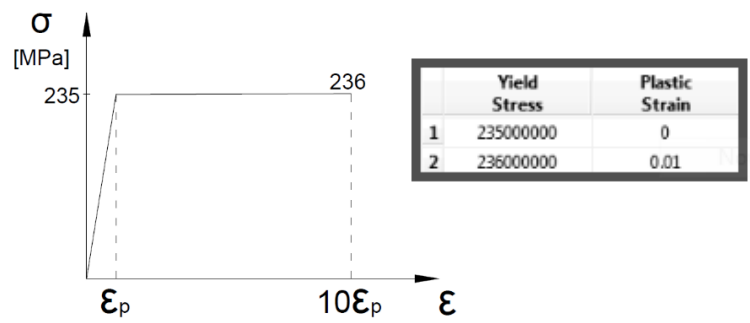

Fig 7. Elastic - plastic steel model with yielding plateau and minimal, linear strain hardening

The computations were performer using one of three computations procedures: Static General (elastic range analysis) and Static Riks and Buckle (elastic - plastic range analysis) in the Abaqus - Standard program.

\section{THE RESULTS OF NUMERICAL ANALYSIS}

The two - span beam with a cantilever in two variants of length was analysed. The first variant: large span - $12 \mathrm{~m}$, with $4 \mathrm{~m}$ length cantilever, the second variant: small span $-6 \mathrm{~m}$ with $2 \mathrm{~m}$ length cantilever. The cross section depth is equal to $1 / 12$ span. The distributed load $100 \mathrm{kN} / \mathrm{m}$ was applied on the entire length of the beam. In the computations the weight of the construction was omitted.

According to the Eurocode 3 part $1-5[8]$ it is obligatory to take into account the shear lag effect when the half width of the flange is less then effective length (the length between adjacent points of zero bending moment) divided by 50 . The shear lag effect occurs for the chosen dimensions of the cross sections.

a)

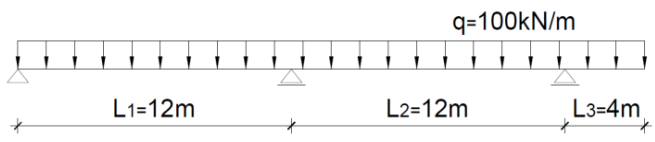

b)

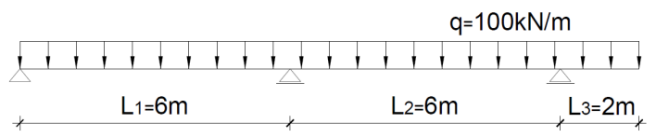

Fig. 8 The static scheme of the analysed beams: a) variant I, b) variant II 


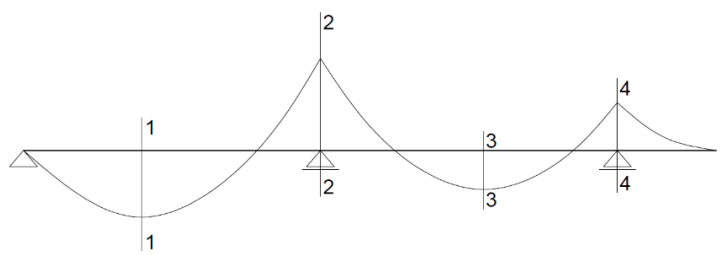

Fig. 9 Analysed sections

Firstly, calculations according to the norm EN 1993-1-5 [8] were performed, using the algorithm described in example given in [1]. Then, results were compared with the numerical computations performed by Abaqus. The aim of the task was to determine the shear forces and bending moments distribution in the beam with a wide flange. Then, the analysis of the stress distribution in the upper flange (in 2-2 and 4-4 sections) was performed.

\subsection{ELASTIC SHEAR LAG EFFECT}

Figure 10 presents the analysed cross sections dimensions in the elastic range. Table 1 presents the calculation steps needed to determine the effective width (according to the procedures of Eurocode 3 standard). To perform the numerical computations in the elastic range the Static, General procedure was used.

a)

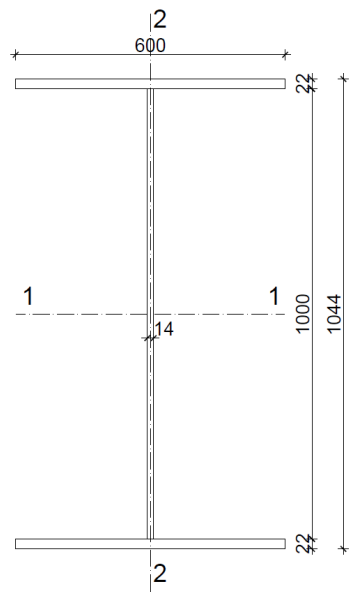

b)

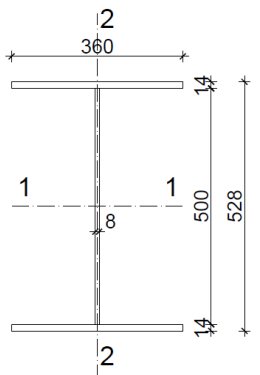

Fig. 10 The cross section of the analysed plated structural element: a) variant I, b) variant II 
The beam with reduced stiffness was modelled in the program for bar structures computation (according to the scheme presented in the Figure 11). The determined values of the internal forces and stresses in characteristic sections were compared with the values from numerical analysis.

The comparison was performed in the Table 2 and 3.

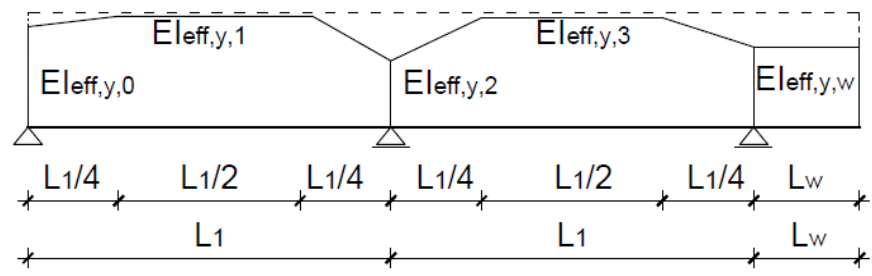

Fig. 11 The reduced stiffness of the cross section

Table 1. Effective width of the flange by [8]

\begin{tabular}{|c|c|c|c|c|c|}
\hline \multicolumn{2}{|l|}{ Data } & Symbol & Unit & Large span & Small span \\
\hline \multicolumn{2}{|c|}{ Moment of inertia of the gross cross section } & $\mathrm{I}_{\mathrm{y}}$ & $\mathrm{cm}^{4}$ & 806133 & 74927 \\
\hline \multirow{4}{*}{\multicolumn{2}{|c|}{ Effective length }} & $\mathrm{L}_{\mathrm{el}}$ & $\mathrm{m}$ & 10.2 & 5.1 \\
\hline & & $\mathrm{L}_{\mathrm{e} 2}$ & $\mathrm{~m}$ & 6.0 & 3.0 \\
\hline & & $\mathrm{L}_{\mathrm{e} 3}$ & $\mathrm{~m}$ & 8.4 & 4.2 \\
\hline & & $\mathrm{L}_{\mathrm{e} 4}$ & $\mathrm{~m}$ & 8.0 & 4.0 \\
\hline \multirow{5}{*}{ Factor $\kappa$} & end support & $\kappa_{0}$ & - & 0.0294 & 0,0353 \\
\hline & end span & $\kappa_{1}$ & - & 0.0294 & 0.0353 \\
\hline & middle support & $\kappa_{2}$ & - & 0.0500 & 0.0600 \\
\hline & middle span & $\kappa_{3}$ & - & 0.0357 & 0.0429 \\
\hline & cantilever & $\kappa_{\mathrm{W}}$ & - & 0.0375 & 0.0450 \\
\hline \multirow{5}{*}{ Effective width factor } & end support & $\beta_{0}$ & - & 0.994 & 0.992 \\
\hline & end span & $\beta_{1}$ & - & 0.994 & 0.992 \\
\hline & middle support & $\beta_{2}$ & - & 0.796 & 0.754 \\
\hline & middle span & $\beta_{3}$ & - & 0.992 & 0.992 \\
\hline & cantilever & $\beta_{\mathrm{w}}$ & - & 0.860 & 0.820 \\
\hline \multirow{5}{*}{ Effective width of the flange } & end support & $\mathrm{b}_{\mathrm{eff}, 0}$ & $\mathrm{~mm}$ & 597 & 357 \\
\hline & end span & $\mathrm{b}_{\mathrm{eff}, 1}$ & $\mathrm{~mm}$ & 597 & 357 \\
\hline & middle support & $b_{\text {eff }, 2}$ & $\mathrm{~mm}$ & 478 & 272 \\
\hline & middle span & $b_{\text {eff }, 3}$ & $\mathrm{~mm}$ & 595 & 356 \\
\hline & cantilever & $\mathrm{b}_{\mathrm{eff}, \mathrm{w}}$ & $\mathrm{mm}$ & 516 & 295 \\
\hline \multirow{5}{*}{\multicolumn{2}{|c|}{ Moment of inertia of the net cross section }} & $\mathrm{I}_{\mathrm{eff}, \mathrm{y}, 0}$ & $\mathrm{~cm}^{4}$ & 802685 & 74372 \\
\hline & & $\mathrm{I}_{\mathrm{eff}, \mathrm{y}, 1}$ & $\mathrm{~cm}^{4}$ & 802685 & 74372 \\
\hline & & $\mathrm{I}_{\mathrm{eff}, \mathrm{y}, 2}$ & $\mathrm{~cm}^{4}$ & 665941 & 58649 \\
\hline & & $\mathrm{I}_{\mathrm{eff}, \mathrm{y}, 3}$ & $\mathrm{~cm}^{4}$ & 800387 & 74187 \\
\hline & & $\mathrm{I}_{\mathrm{eff}, \mathrm{y}, \mathrm{w}}$ & $\mathrm{cm}^{4}$ & 709607 & 62903 \\
\hline \multicolumn{6}{|c|}{ All symbols which are included in this table are the symbols from Eurocode 3 [8] } \\
\hline
\end{tabular}


Table 2. Internal forces

\begin{tabular}{|c|c|c|c|c|c|c|c|c|}
\hline \multirow{3}{*}{ Data } & \multirow{3}{*}{$\begin{array}{c}\text { Cross } \\
\text { section }\end{array}$} & \multirow{3}{*}{ Unit } & \multicolumn{3}{|c|}{ Large span } & \multicolumn{3}{|c|}{ Small span } \\
\hline & & & \multicolumn{2}{|c|}{ Analytical results } & \multirow[b]{2}{*}{$\begin{array}{l}\text { Numerica } \\
1 \text { results }\end{array}$} & \multicolumn{2}{|c|}{ Analytical results } & \multirow[b]{2}{*}{$\begin{array}{l}\text { Numerical } \\
\text { results }\end{array}$} \\
\hline & & & $\begin{array}{c}\text { Gross } \\
\text { cross } \\
\text { section }\end{array}$ & $\begin{array}{c}\text { Net cross } \\
\text { section }\end{array}$ & & $\begin{array}{c}\text { Gross cross } \\
\text { section }\end{array}$ & $\begin{array}{l}\text { Net cross } \\
\text { section }\end{array}$ & \\
\hline \multirow{4}{*}{$\begin{array}{l}\text { Bending } \\
\text { moment }\end{array}$} & $1-1$ & $\mathrm{kNm}$ & 1088.9 & 1113.6 & 1088.9 & 272.2 & 280.1 & 277.7 \\
\hline & $2-2$ & $\mathrm{kNm}$ & 1600.0 & 1536.9 & 1600.0 & 400.0 & 378.0 & 381.8 \\
\hline & $3-3$ & $\mathrm{kNm}$ & 622.2 & 650.4 & 622.2 & 155.6 & 164.5 & 162.2 \\
\hline & $4-4$ & $\mathrm{kNm}$ & 800.0 & 800.0 & 800.0 & 200.0 & 200.0 & 198.0 \\
\hline \multirow{4}{*}{$\begin{array}{l}\text { Shear } \\
\text { force }\end{array}$} & $2-2$ (left) & $\mathrm{kN}$ & 733.3 & 728.1 & 733.3 & 366.7 & 363.3 & 359.2 \\
\hline & $2-2$ (right) & $\mathrm{kN}$ & 666.7 & 661.4 & 666.7 & 333.3 & 330.0 & 329.3 \\
\hline & 4-4 (left) & $\mathrm{kN}$ & 533.3 & 538.6 & 533.3 & 266.7 & 270.0 & 264.2 \\
\hline & 4-4 (right) & $\mathrm{kN}$ & 400.0 & 400.0 & 400.0 & 200.0 & 200.0 & 198.6 \\
\hline
\end{tabular}

Table 3. Stress values in the upper flange

\begin{tabular}{|c|c|c|c|c|c|c|c|}
\hline & \multirow{3}{*}{ Section } & \multicolumn{3}{|c|}{ Large span } & \multicolumn{3}{|c|}{ Small span } \\
\hline & & \multicolumn{2}{|c|}{ Stress $[\mathrm{MPa}]$} & \multirow{2}{*}{$\begin{array}{l}\text { Percentage } \\
\text { difference }\end{array}$} & Stress [MPa] & \multicolumn{2}{|c|}{ Percentage difference } \\
\hline & & $\begin{array}{c}\text { Analytical } \\
\text { results }\end{array}$ & $\begin{array}{c}\text { Numerical } \\
\text { results }\end{array}$ & & $\begin{array}{c}\text { Analytical } \\
\text { results }\end{array}$ & $\begin{array}{c}\text { Numerical } \\
\text { results }\end{array}$ & \\
\hline \multirow{2}{*}{$2-2$} & Max. stress & 120.5 & 126.0 & $4.4 \%$ & 170.2 & 174.1 & $2.2 \%$ \\
\hline & Min. stress & 89.8 & 91.8 & $2.2 \%$ & 117.9 & 124.5 & $5.3 \%$ \\
\hline \multirow{2}{*}{$4-4$} & Max. stress & 58.8 & 72.8 & $19.2 \%$ & 83.9 & 106.9 & $21.5 \%$ \\
\hline & Min. stress & 48.6 & 46.0 & $5.7 \%$ & 65.0 & 63.1 & $3.0 \%$ \\
\hline
\end{tabular}

Additionally the influence of stiffeners on the stress distribution in the width flanges was analysed. The beams calculated above were modelled using the stiffeners. The comparison of the results in the table below was performed.

Table 4. The value of the stress in beam with and without stiffeners

\begin{tabular}{|l|l|c|c|c|c|}
\hline \multirow{2}{*}{ Cross section } & \multicolumn{2}{|c|}{ Large span } & \multicolumn{2}{c|}{ Small span } \\
\cline { 3 - 6 } \multicolumn{2}{|c|}{} & \multicolumn{2}{|c|}{ Stress [MPa] } & \multicolumn{2}{c|}{ Stress [MPa] } \\
\cline { 2 - 6 } \multicolumn{2}{|c|}{} & $\begin{array}{c}\text { Without } \\
\text { stiffeners }\end{array}$ & $\begin{array}{c}\text { With } \\
\text { stiffeners }\end{array}$ & $\begin{array}{c}\text { Without } \\
\text { stiffeners }\end{array}$ & $\begin{array}{c}\text { With } \\
\text { stiffeners }\end{array}$ \\
\hline \multirow{2}{*}{$2-2$} & Max. stress & 126.0 & 101.4 & 174.1 & 135.3 \\
\cline { 2 - 6 } & Min. stress & 91.8 & 92.8 & 124.5 & 116.1 \\
\hline \multirow{2}{*}{$4-4$} & Max. stress & 72.8 & 54.6 & 106.9 & 73.0 \\
\cline { 2 - 6 } & Min. stress & 46.0 & 46.4 & 63.1 & 62.0 \\
\hline
\end{tabular}

\subsection{COMBINED EFFECTS OF SHEAR LAG AND PLATE BUCKLING}

In the next step of the combined effects of shear lag and plate buckling were analysed. The first cross section of the flange was reduced from 22 to $14 \mathrm{~mm}$ and the second cross section was reduced from 14 to $10 \mathrm{~mm}$ in order to classify them to the 4 class. 
To perform the calculations in elastic range with effects of plate buckling the Static, General procedure with geometrical nonlinearity was used.

a)

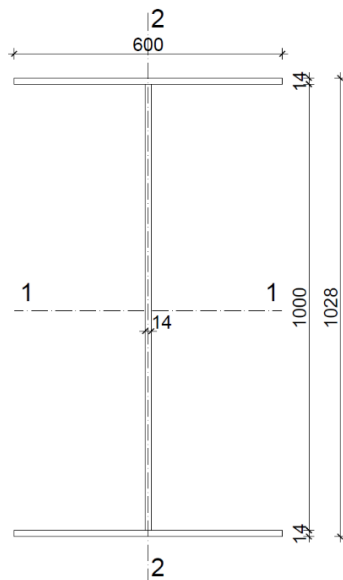

b)

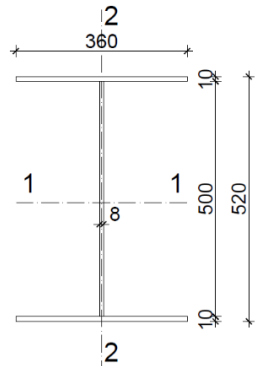

Fig. 12. The cross section of the analysed plated structural element: a) variant I, b) variant II

Table 5. Effective width of the flange [8]

\begin{tabular}{|c|c|c|c|c|c|}
\hline \multicolumn{2}{|l|}{ Data } & Symbol & Unit & Large span & Small span \\
\hline \multicolumn{2}{|c|}{ Moment of inertia of the gross cross section } & $\mathrm{I}_{\mathrm{y}}$ & $\mathrm{cm}^{4}$ & 488075 & 55157 \\
\hline \multirow{5}{*}{ Factor $\kappa$} & end support & $\kappa_{0}$ & - & 0.035 & 0.046 \\
\hline & end span & $\kappa_{1}$ & - & 0.035 & 0.046 \\
\hline & middle support & $\kappa_{2}$ & - & 0.060 & 0.077 \\
\hline & middle span & $\kappa_{3}$ & - & 0.043 & 0.055 \\
\hline & cantilever & $\kappa_{W}$ & - & 0.045 & 0.058 \\
\hline \multirow{5}{*}{ Effective width factor } & end support & $\beta_{0}$ & - & 0.992 & 0.987 \\
\hline & end span & $\beta_{1}$ & - & 0.992 & 0.987 \\
\hline & middle support & $\beta_{2}$ & - & 0.753 & 0.693 \\
\hline & middle span & $\beta_{3}$ & - & 0.988 & 0.981 \\
\hline & cantilever & $\beta_{\mathrm{w}}$ & - & 0.992 & 0.762 \\
\hline \multirow{5}{*}{ Effective width of the compression flange } & end support & $\mathrm{b}_{\mathrm{eff}, 0}$ & $\mathrm{~mm}$ & 432 & 296 \\
\hline & end span & $\mathrm{b}_{\text {eff }, 1}$ & $\mathrm{~mm}$ & 432 & 296 \\
\hline & middle support & $b_{\text {eff }, 2}$ & $\mathrm{~mm}$ & 328 & 208 \\
\hline & middle span & $\mathrm{b}_{\text {eff }, 3}$ & $\mathrm{~mm}$ & 431 & 294 \\
\hline & cantilever & $\mathrm{b}_{\text {eff,w }}$ & $\mathrm{mm}$ & 358 & 229 \\
\hline \multirow{5}{*}{ Effective width of the tension flange } & end support & $\mathrm{b}_{\mathrm{eff}, 0}$ & $\mathrm{~mm}$ & 595 & 355 \\
\hline & end span & $\mathrm{b}_{\text {eff }, 1}$ & $\mathrm{~mm}$ & 595 & 355 \\
\hline & middle support & $\mathrm{b}_{\text {eff }, 2}$ & $\mathrm{~mm}$ & 452 & 249 \\
\hline & middle span & $\mathrm{b}_{\text {eff }, 3}$ & $\mathrm{~mm}$ & 593 & 353 \\
\hline & cantilever & $b_{\text {eff,w }}$ & $\mathrm{mm}$ & 492 & 274 \\
\hline \multirow{5}{*}{\multicolumn{2}{|c|}{ Moment of inertia of the net cross section }} & $\mathrm{I}_{\mathrm{eff}, \mathrm{y}, 0}$ & $\mathrm{~cm}^{4}$ & 481558 & 50455 \\
\hline & & $\mathrm{I}_{\mathrm{eff}, \mathrm{y}, 1}$ & $\mathrm{~cm}^{4}$ & 481558 & 50455 \\
\hline & & $\mathrm{I}_{\mathrm{eff}, \mathrm{y}, 2}$ & $\mathrm{~cm}^{4}$ & 394273 & 37926 \\
\hline & & $\mathrm{I}_{\mathrm{eff}, \mathrm{y}, 3}$ & $\mathrm{~cm}^{4}$ & 480529 & 50194 \\
\hline & & $\mathrm{I}_{\text {eff,y,w }}$ & $\mathrm{cm}^{4}$ & 419082 & 40899 \\
\hline
\end{tabular}


Table 6. Internal forces

\begin{tabular}{|c|c|c|c|c|c|c|c|c|}
\hline \multirow{3}{*}{ Data } & \multirow{3}{*}{$\begin{array}{l}\text { Cross } \\
\text { section }\end{array}$} & \multirow{3}{*}{ Unit } & \multicolumn{3}{|c|}{ Large span } & \multicolumn{3}{|c|}{ Small span } \\
\hline & & & \multicolumn{2}{|c|}{ Analytical results } & \multirow{2}{*}{$\begin{array}{l}\text { Numerical } \\
\text { results }\end{array}$} & \multicolumn{2}{|c|}{ Analytical results } & \multirow{2}{*}{$\begin{array}{l}\text { Numerical } \\
\text { results }\end{array}$} \\
\hline & & & $\begin{array}{c}\text { Gross cross } \\
\text { section }\end{array}$ & $\begin{array}{c}\text { Net cross } \\
\text { section }\end{array}$ & & $\begin{array}{c}\text { Gross cross } \\
\text { section }\end{array}$ & $\begin{array}{c}\text { Net cross } \\
\text { section }\end{array}$ & \\
\hline \multirow{4}{*}{$\begin{array}{l}\text { Bending } \\
\text { moment }\end{array}$} & $1-1$ & $\mathrm{kNm}$ & 1088.9 & 1114.2 & 1103.0 & 272.2 & 281.5 & 277.0 \\
\hline & $2-2$ & $\mathrm{kNm}$ & 1600.0 & 1535.2 & 1562.0 & 400.0 & 376.3 & 385.8 \\
\hline & $3-3$ & $\mathrm{kNm}$ & 622.2 & 651.1 & 638.4 & 155.6 & 166.2 & 161.1 \\
\hline & $4-4$ & $\mathrm{kNm}$ & 800.0 & 800.0 & 797.5 & 200.0 & 200.0 & 198.4 \\
\hline \multirow{4}{*}{$\begin{array}{l}\text { Shear } \\
\text { force }\end{array}$} & 2-2 (left) & $\mathrm{kN}$ & 733.3 & 727.9 & 727.9 & 366.7 & 362.7 & 364.7 \\
\hline & $2-2$ (right) & $\mathrm{kN}$ & 666.7 & 661.3 & 659.5 & 333.3 & 329.4 & 329.5 \\
\hline & 4-4 (left) & $\mathrm{kN}$ & 533.3 & 538.7 & 535.4 & 266.7 & 270.6 & 268.4 \\
\hline & $4-4$ (right) & $\mathrm{kN}$ & 400.0 & 400.0 & 396.0 & 200.0 & 200.0 & 198.0 \\
\hline
\end{tabular}

Table 7. Stress values in the upper flange

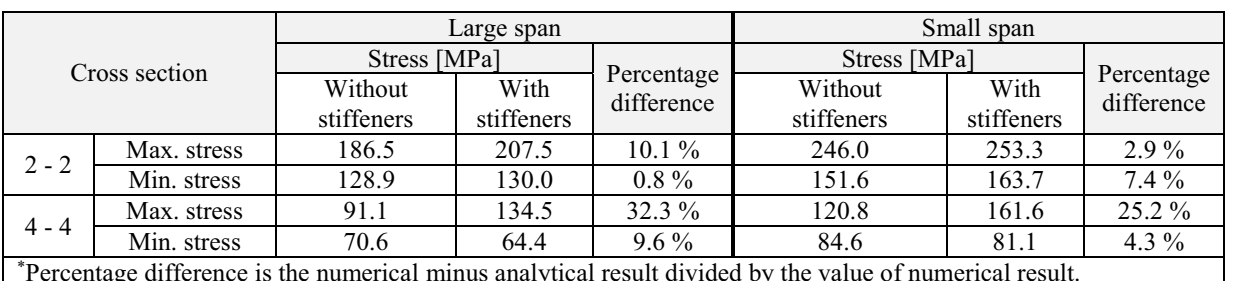

In the table 5 the data needed for analytical computations according to the Eurocode 3 [8] were presented. The in the tables 6 and 7 the comparison of the analytical and numerical results (the values of internal forces and the stress values) was shown. The difference between the values of the stress is smaller in the case of minimal stress then in the case of maximum stress (in the web axis).

\subsection{ELASTIC - PLASTIC SHEAR LAG EFFECT}

The last step of the analysis included the combined effects of elastic - plastic shear lag effect with limited plastic strains and of plate buckling. The beams as in subsection 4.2 with elastic - plastic model of steel were analysed. This type of analysis was also presented in [7]. In order to determine the limit load for class 4 cross sections in elastic - plastic range the two types of analysis: Buckle and Static Riks ware used. The first type of analysis - Buckle - is used to determine the form of the stability loss. Then, the Static Riks analysis which takes into account the geometric imperfections were performed. The results from the first analysis were scaled, so imperfections do not exceed the limit values, according to the standard [9]. Then, the obtained values were loaded to the Static Riks procedure.

The beams were divided into sections on the entire width of the flange with a value of $100 \mathrm{kN} / \mathrm{m}^{2}$. The load increase (from the chart LPF - Load Proportionality Factor) was observed during Static 
Riks analysis. When this function has reached the maximum value and the load started to decrease the loss of stability and bearing capacity occurred. The value of maximum load was read from the LPF diagram and for this value the analytical calculations according to the standard [8] were performed.

a)
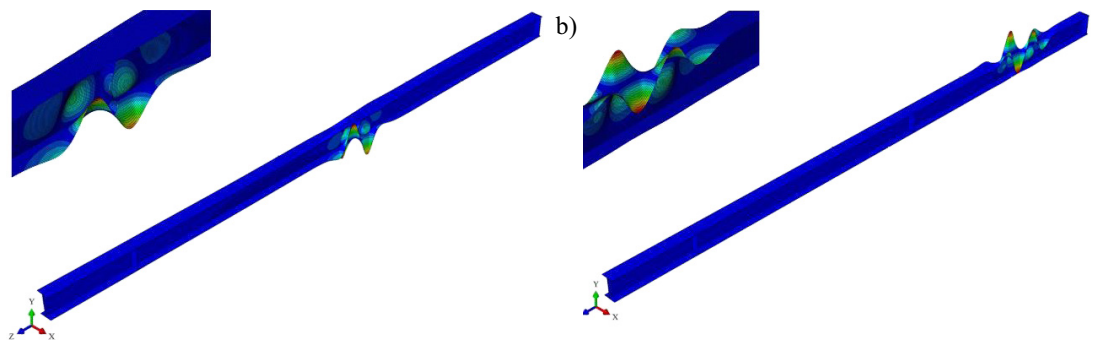

Fig. 13. The mode illustrating forms of the local loss of stability: a) first form, b) second form.

a)

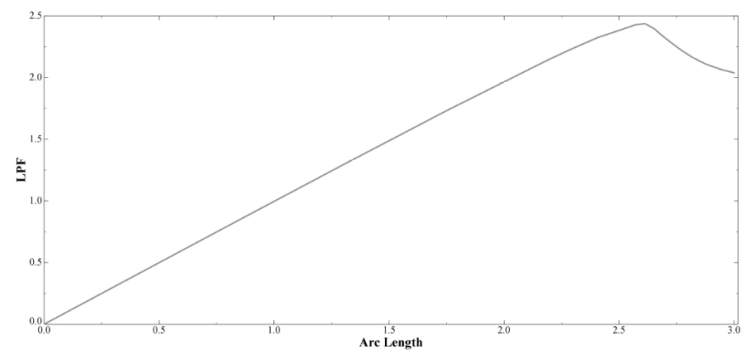

b)

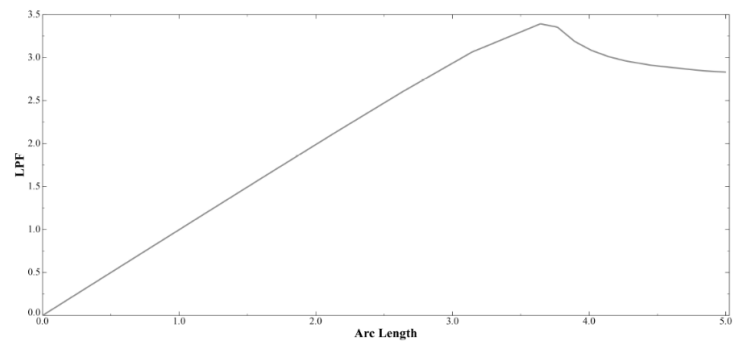

Fig. 14. Load proportionality factor: a) variant I $(\mathrm{LPF}=2.438), \mathrm{b})$ variant II $(\mathrm{LPF}=3.393)$. 
Table 8. Effective width of the flange [8]

\begin{tabular}{|c|c|c|c|c|c|}
\hline \multicolumn{2}{|l|}{ Data } & Symbol & Unit & $\begin{array}{c}\text { Large } \\
\text { span }\end{array}$ & $\begin{array}{c}\text { Small } \\
\text { span }\end{array}$ \\
\hline \multirow{5}{*}{ Effective width of the compression flange } & end support & beff, 0 & $\mathrm{~mm}$ & 436 & 300 \\
\hline & end span & beff, 1 & $\mathrm{~mm}$ & 436 & 300 \\
\hline & middle support & beff, 2 & $\mathrm{~mm}$ & 429 & 292 \\
\hline & middle span & beff,3 & $\mathrm{mm}$ & 436 & 300 \\
\hline & cantilever & beff,w & $\mathrm{mm}$ & 432 & 292 \\
\hline \multirow{5}{*}{ Effective width of the tension flange } & end support & beff, 0 & $\mathrm{~mm}$ & 600 & 360 \\
\hline & end span & beff, 1 & $\mathrm{~mm}$ & 600 & 360 \\
\hline & middle support & beff, 2 & $\mathrm{~mm}$ & 590 & 350 \\
\hline & middle span & beff,3 & $\mathrm{mm}$ & 600 & 360 \\
\hline & cantilever & beff,w & $\mathrm{mm}$ & 595 & 354 \\
\hline \multirow{5}{*}{ Moment of inertia of the net cross section } & & Ieff,y, 0 & $\mathrm{~cm} 4$ & 488942 & 51035 \\
\hline & & Ieff,y,1 & $\mathrm{cm} 4$ & 488942 & 51035 \\
\hline & & Ieff,y,2 & $\mathrm{cm} 4$ & 478776 & 49875 \\
\hline & & Ieff,y,3 & $\mathrm{cm} 4$ & 484760 & 51035 \\
\hline & & Ieff,y,w & $\mathrm{cm} 4$ & 487558 & 50324 \\
\hline
\end{tabular}

Table 9. Internal forces

\begin{tabular}{|c|c|c|c|c|c|c|c|c|}
\hline \multirow{3}{*}{ Data } & \multirow{3}{*}{$\begin{array}{l}\text { Cross } \\
\text { section }\end{array}$} & \multirow{3}{*}{ Unit } & \multicolumn{3}{|c|}{ Large span } & \multicolumn{3}{|c|}{ Small span } \\
\hline & & & \multicolumn{2}{|c|}{ Analytical results } & \multirow[b]{2}{*}{$\begin{array}{l}\text { Numerical } \\
\text { results }\end{array}$} & \multicolumn{2}{|c|}{ Analytical results } & \multirow[b]{2}{*}{$\begin{array}{l}\text { Numerica } \\
\text { results }\end{array}$} \\
\hline & & & $\begin{array}{c}\text { Gross cross } \\
\text { section }\end{array}$ & $\begin{array}{l}\text { Net cross } \\
\text { section }\end{array}$ & & $\begin{array}{c}\text { Gross cross } \\
\text { section }\end{array}$ & $\begin{array}{c}\text { Net cross } \\
\text { section }\end{array}$ & \\
\hline \multirow{4}{*}{$\begin{array}{l}\text { Bending } \\
\text { moment }\end{array}$} & $1-1$ & $\mathrm{kNm}$ & 1088.9 & 1593.6 & 1624.0 & 272.2 & 332.7 & 343.6 \\
\hline & $2-2$ & $\mathrm{kNm}$ & 1600.0 & 2339.1 & 2228.0 & 400.0 & 486.4 & 456.9 \\
\hline & $3-3$ & $\mathrm{kNm}$ & 622.2 & 911.1 & 949.2 & 155.6 & 190.8 & 202.5 \\
\hline & $4-4$ & $\mathrm{kNm}$ & 800.0 & 1170.4 & 1159.0 & 200.0 & 244.2 & 241.7 \\
\hline \multirow{4}{*}{$\begin{array}{l}\text { Shear } \\
\text { force }\end{array}$} & $2-2$ (left) & $\mathrm{kN}$ & 733.3 & 1072.2 & 1034.0 & 366.7 & 447.4 & 434.8 \\
\hline & 2-2 (right) & $\mathrm{kN}$ & 666.7 & 975.2 & 937.2 & 333.3 & 406.7 & 394.0 \\
\hline & 4-4 (left) & $\mathrm{kN}$ & 533.3 & 780.4 & 772.8 & 266.7 & 325.9 & 326.1 \\
\hline & 4-4 (right) & $\mathrm{kN}$ & 400.0 & 585.2 & 517.5 & 200.0 & 244.2 & 240.3 \\
\hline
\end{tabular}

Table 9. Internal forces

\begin{tabular}{|c|c|c|c|c|c|c|c|c|}
\hline \multirow{3}{*}{ Data } & \multirow{3}{*}{$\begin{array}{l}\text { Cross } \\
\text { section }\end{array}$} & \multirow{3}{*}{ Unit } & \multicolumn{3}{|c|}{ Large span } & \multicolumn{3}{|c|}{ Small span } \\
\hline & & & \multicolumn{2}{|c|}{ Analytical results } & \multirow{2}{*}{$\begin{array}{l}\text { Numerical } \\
\text { results }\end{array}$} & \multicolumn{2}{|c|}{ Analytical results } & \multirow{2}{*}{$\begin{array}{l}\text { Numerical } \\
\text { results }\end{array}$} \\
\hline & & & $\begin{array}{c}\text { Gross cross } \\
\text { section }\end{array}$ & $\begin{array}{c}\text { Net cross } \\
\text { section }\end{array}$ & & $\begin{array}{c}\text { Gross cross } \\
\text { section }\end{array}$ & $\begin{array}{c}\text { Net cross } \\
\text { section }\end{array}$ & \\
\hline \multirow{4}{*}{$\begin{array}{l}\text { Bending } \\
\text { moment }\end{array}$} & $1-1$ & $\mathrm{kNm}$ & 1088.9 & 1593.6 & 1624.0 & 272.2 & 332.7 & 343.6 \\
\hline & $2-2$ & $\mathrm{kNm}$ & 1600.0 & 2339.1 & 2228.0 & 400.0 & 486.4 & 456.9 \\
\hline & $3-3$ & $\mathrm{kNm}$ & 622.2 & 911.1 & 949.2 & 155.6 & 190.8 & 202.5 \\
\hline & $4-4$ & $\mathrm{kNm}$ & 800.0 & 1170.4 & 1159.0 & 200.0 & 244.2 & 241.7 \\
\hline \multirow{4}{*}{$\begin{array}{l}\text { Shear } \\
\text { force }\end{array}$} & $2-2$ (left) & $\mathrm{kN}$ & 733.3 & 1072.2 & 1034.0 & 366.7 & 447.4 & 434.8 \\
\hline & $2-2$ (right) & $\mathrm{kN}$ & 666.7 & 975.2 & 937.2 & 333.3 & 406.7 & 394.0 \\
\hline & 4-4 (left) & $\mathrm{kN}$ & 533.3 & 780.4 & 772.8 & 266.7 & 325.9 & 326.1 \\
\hline & 4-4 (right) & $\mathrm{kN}$ & 400.0 & 585.2 & 517.5 & 200.0 & 244.2 & 240.3 \\
\hline
\end{tabular}


a)

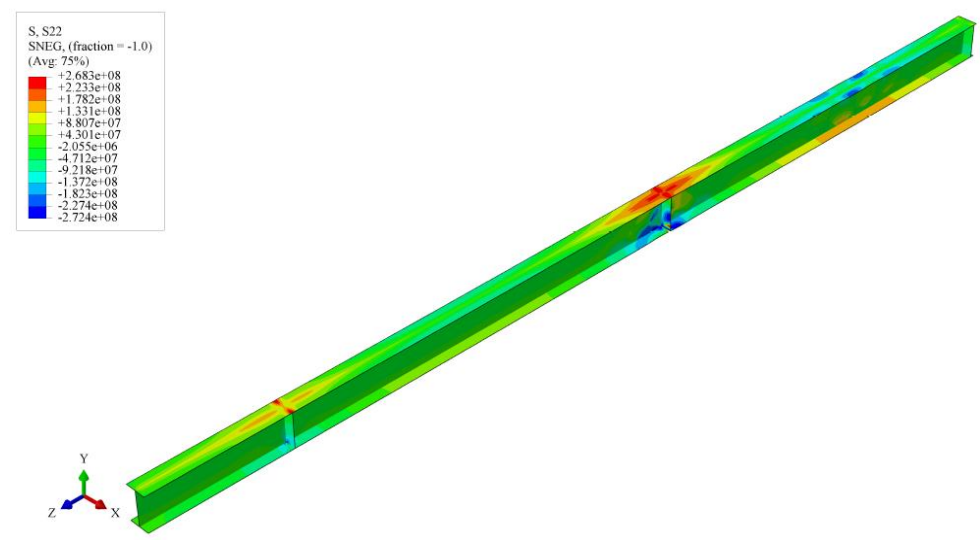

b)

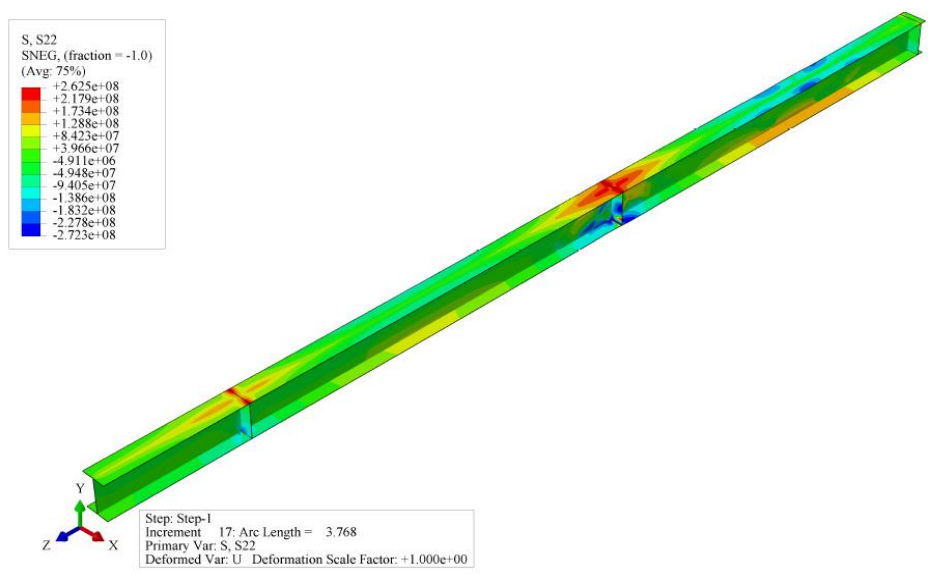

Fig. 15. The normal stress map corresponding to the Mises stress equal $236 \mathrm{MPa}[\mathrm{Pa}]$ :

a) large span beam, b) small span beam.

\section{CONCLUSIONS}

The results and analysis of the performed analytical and numerical calculations led to the following conclusion:

$1^{\circ}$ It was proven that internal forces in beams with wide flanges cannot be calculated according to the elementary theory of bending. In statically indeterminate beams the values of bending moments and shear forces depend on the width of the flange. 
$2^{\circ}$ The calculation method of the internal forces in beams presented in Eurocode 3 gives similar results to the results obtained in the numerical analysis (using Abaqus program). The percentage difference between the analytical and numerical results (in the examples presented in this article) is presented in the table.

Table 10. The percentage difference between presented results

\begin{tabular}{|c|c|c|c|}
\hline Data & $\begin{array}{c}\text { Elastic analysis } \\
\text { without plate } \\
\text { buckling }\end{array}$ & $\begin{array}{c}\text { Elastic analysis } \\
\text { taking into } \\
\text { account the } \\
\text { effect of plate } \\
\text { buckling }\end{array}$ & $\begin{array}{c}\text { Elastic - plastic } \\
\text { analysis taking } \\
\text { into account the } \\
\text { effect of plate } \\
\text { buckling }\end{array}$ \\
\hline $\begin{array}{c}\text { Bending } \\
\text { moment }\end{array}$ & $0.5-1.5 \%$ & $0.4-2.0 \%$ & $1.0-5.0 \%$ \\
\hline $\begin{array}{c}\text { Shear } \\
\text { force }\end{array}$ & $0.5-2.0 \%$ & $0.0-1.0 \%$ & $1.0-2.0 \%$ \\
\hline
\end{tabular}

$3^{\circ}$ The shear lag effects influence the change of internal forces distribution. Therefore, the static calculation (not only in determining the bearing capacity) must take into account the reduced stiffness of the cross section.

$4^{\circ}$ It was proven that using the numerical computations for the beam with width flanges, the stress values cannot be determined using the classic beam theory, $\left(\sigma_{x}=\frac{M_{y}}{I_{y}} z\right)$ because the stress distribution in the flange is not constant. The maximum value of the stress is in the web axis and minimal on the edge of the flange. The decrease of the stress distribution describes the non - linear function. It can be concluded that the function equation given in Eurocode 3 gives results consistent with the results obtained in the numerical analysis.

$5^{\circ}$ The shear lag effect is more evident in shorter beams. This means that the value of the effective width factor $\beta$ increases with increasing the span of the beam.

$6^{\circ}$ The use of stiffeners reduces the effect of non-linear stress distribution in the wide flange. The maximum stress $\sigma_{22(l)}$ in the web axis may be lowered by using stiffeners (about $26 \%$ for middle support and $46 \%$ for support next to the cantilever). However, the minimum stress $\sigma_{22(2)}$ on the edge of the flange may increase or decrease about $5 \%$. Therefore, the difference between maximum and minimum values of the stress are lowered by using the stiffeners (the lower influence of shear lag effect). 


\section{REFERENCES}

1. Goczek J., Supeł Ł., Gajdzicki M., Przykłady obliczeń konstrukcji stalowych, Lodz University of Technology, Poland, 2010

2. Jankowiak R., Elementy smukłościenne (blachownice) - obliczenia i kształtowanie, XXVII Ogólnopolskie warsztaty pracy projektanta konstrukcji, Szczyrk, marzec 2012

3. Johansson B., Maquoi R., Sedlacek G., Müller C., Beg D. Commentary and worked examples to EN 1993-1-5 Plated structuralelements, JRC Scientific and Technical Raports, First Edition, October 2007

4. Sa - nguanmanasak J., Stress concentration due to shear lag in simply supported box girders with longitudinal stiffeners and continuous box girders and finite element modeling of steel - Concrete composite bridge, Sirindhorn International Institute of Technology, Thammasat University, Thailand, May 2010

5. Sørensen R. K., Evaluation of shear lag in standard H-/I-sections, Aalborg University Esbjerg, Denmark, 2013

6. Kármán, Th. Von, The effective width (in German), Beitrage zur technischen Mechanik, p. 114127, Springer-Verlag Berlin Heidelberg Gmbh, German, 1924

7. Piekarczyk M., Wykorzystanie nadkrytycznej rezerwy nośności w projektowaniu konstrukcji stalowych, Tadeusz Kosciuszko Cracow University of Technology, Poland, 2002

8. EN 1993-1-5, Eurocode 3, Design of steel structures - Part 1-5 Plated structural elements, 2006

9. PN-EN 1090-2, Wykonywanie konstrukcji stalowych i aluminiowych, Część 2: Wymaganie techniczne dotyczące konstrukcji stalowych, 2012

10. Abaqus 6.10 Documentation, "Abaqus/CEA User's Manual".

11. Abaqus 6.10 Documentation, "Abaqus Analysis User's Manual”.

\section{LIST OF FIGURES AND TABLES:}

Fig. 1. Stress distribution in width flange [8]

Rys. 1. Schematyczny rozkład naprężeń w szerokim pasie [8]

Fig. 2. The final shape of the warping function [3]

Rys. 2. Ostateczny kształt funkcji spaczenia [3]

Fig. 3. Stress distribution with the shear lag effect [3]

Rys. 3. Rozkład naprężeń wywołany efektem szerokiego pasa [3]

Fig. 4. The shape ratio [5]

Rys. 4. Współczynnik kształtu [5]

Fig. 5. Effective width factor depending on the distribution of the bending moment [3]

Rys. 5. Współczynnik szerokości efektywnej w zależności od rozkładu momentu zginającego [3]

Fig. 6. Shell model of the plated structural element without and with the stiffeners

Rys. 6. Powłokowy model blachownicy bez oraz z żeberkami usztywniającymi

Fig 7. Elastic - plastic steel model with yielding plateau and minimal, linear strain hardening

Rys. 7. Sprężysto - plastyczny model stali z półką plastyczną i minimalnym wzmocnieniem

Fig. 8. The static scheme of the analysed beams: a) variant I, b) variant II

Rys. 8. Schemat statyczny analizowanej belki: a) wariant I, b) wariant II.

Fig. 9. Analysed sections

Rys. 9. Numeracja analizowanych przekrojów 
Fig. 10. The cross section of the analysed plated structural element: a) variant I, b) variant II Rys. 10. Przekrój analizowanej blachownicy: a) wariant I, b) wariant II

Fig. 11. The reduced stiffness of the cross section

Rys. 11. Zredukowana sztywność przekroju

Fig. 12. The cross section of the analysed plated structural element: a) variant I, b) variant II

Rys. 12. Przekrój analizowanej blachownicy: a) wariant I, b) wariant II

Fig. 13. The mode illustrating forms of the local loss of stability: a) first form, b) second form

Rys. 13. Moda ilustrująca postacie lokalnej utraty stateczności: a) pierwsza postać, b) druga postać

Fig. 14. Load proportionality factor: a) variant I $(\mathrm{LPF}=2.438)$, b) variant II $(\mathrm{LPF}=3.393)$

Fig. 15. The normal stress map corresponding to the Mises stress equal $236 \mathrm{MPa}[\mathrm{Pa}]$ : a) large span beam,

b) small span beam

Rys. 15. Mapy naprężeń normalnych odpowiadających naprężeniom Misesa równym $236 \mathrm{MPa}$ [Pa]: a) belka o dużej rozpiętości, b) belka o małej rozpiętości

Tab. 1. Effective width of the flange by [8]

Tab. 1. Szerokość efektywna pasa wg [8]

Tab. 2. Internal forces

Tab. 2. Siły wewnętrzne

Tab. 3. Stress values in the upper flange

Tab. 3. Wartości naprężeń w pasie górnym

Tab. 4. The value of the stress in beam with and without stiffeners

Tab. 4. Wartości naprężeń w belce bez i z żeberkami usztywniającymi

Tab. 5. Effective width of the flange by [8]

Tab. 5. Szerokość efektywna pasa wg [8]

Tab. 6. Internal forces

Tab. 6. Siły wewnętrzne

Tab. 7. Stress values in the upper flange

Tab. 7. Wartości naprężeń w pasie górnym

Tab. 8. Effective width of the flange by [8]

Tab. 8. Szerokość efektywna pasa wg [8]

Tab. 9. Internal forces

Tab. 9. Siły wewnętrzne

Tab. 10. The percentage difference between presented results

Tab. 10. Różnica procentowa pomiędzy wynikami 


\section{EFEKT „SZEROKIEGO PASA” W EKSPERYMENCIE NUMERYCZNYM}

Slowa kluczowe: Eurokod 3, analiza numeryczna, blachownice, efekt szerokiego pasa

\section{STRESZCZENIE:}

Norma PN-EN_1993-1-5: 2008 (Eurocode 3) w porównaniu do dotychczas obowiązującej w Polsce normie dotyczącej projektowania konstrukcji stalowych (PN-B-03200: 1990) wprowadza rozszerzone zasady obliczania nośności konstrukcji blachownicowych o uwzględnianie efektu „szerokiego pasa”. Rozkład naprężeń w szerokich pasach jest zmienny i z tego powodu w przypadku belek podlegających efektowi szerokiego pasa nie można przeprowadzać obliczeń według klasycznej teorii belkowej.

W artykule można wyróżnić dwie główne części: pierwszą zawierającą wstęp oraz teoretyczny opis podstaw dotyczących szerokości efektywnej i efektu szerokiego pasa (rozdziały pierwszy i drugi) oraz drugą przedstawiającą wyniki obliczeń analitycznych i numerycznych wpływu efektu szerokiego pasa na rozkład sił wewnętrznych (rozdziały trzeci i czwarty). W rozdziale piątym przedstawione zostały wnioski z przeprowadzonych analiz.

W części pierwszej - opisie teoretycznym odniesiono się do pojęcia szerokości efektywnej, która po raz pierwszy została zaprezentowana przez Kármána w 1924 roku. Następnie podano definicję współczynnika $\beta$, który określa wpływ efektu „szerokiego pasa” dla różnych schematów rozkładu momentu zginającego. Przedstawione w artykule wyprowadzenia stanowią podstawę dla gotowych wzorów na uwzględnienie efektu „szerokiego pasa” w projektowaniu elementów stalowych zaprezentowanych w normie EN-1993-1-1.

W drugiej części artykułu przedstawiono obliczenia sił wewnętrznych, rozkładu naprężeń oraz przemieszczeń według zasad zawartych w EN 1993-1-1. Obliczenia przeprowadzono dla belek dwuprzęsłowych z częścią wspornikową (o długości $2 \mathrm{~m}$ ) o małej rozpiętości $(6 \mathrm{~m})$ oraz dużej rozpiętości $(12 \mathrm{~m})$ przęsła. Wysokość przekroju poprzecznego blachownicy przyjęto równą $1 / 12$ rozpiętości przęsła. Założono obciążenie równomiernie rozłożone na całej długości belki równe $100 \mathrm{kN} / \mathrm{m}$. W obliczeniach pomięto ciężar własny konstrukcji. Przeprowadzone obliczenia podzielono na trzy grupy:

1) analizę efektu ,szerokiego pasa” w zakresie sprężystym;

2) analizę efektu ,szerokiego pasa” w zakresie sprężystym z uwzględnieniem wpływu lokalnej utraty stateczności;

3) analizę efektu ,szerokiego pasa” w zakresie sprężysto - plastycznym.

Wyniki otrzymane w wyniku obliczeń analitycznych (zgodnie z normą) porównano z wynikami przeprowadzonej analizy numerycznej (przy użyciu metody elementów skończonych). Stworzono powłokowy, przestrzenny model blachownicy z elementów skończonych typu S4R o wymiarze $2 \times 2 \mathrm{~mm}$. Do obliczeń numerycznych wykorzystano program Abaqus CEA.

W pierwszej grupie obliczeniowej przedstawiono analizę efektu szerokiego pasa jedynie w zakresie sprężystym. Na tym etapie obliczeń analizowano przekroje klasy pierwszej, czyli nieulegające lokalnej utracie stateczności.

Druga grupa obliczeniowa obejmowała przekroje klasy czwartej, ale analiza prowadzona była również tylko w zakresie sprężystym - obliczenia zawierają złożone efekty szerokiego pasa oraz niestateczności ścianki. Do porównania wyników analitycznych w zakresie sprężystym, w obliczeniach numerycznych wykorzystano procedurę obliczeniową typu Static, General.

W ostatniej grupie obliczeniowej przedstawiono obliczenia złożonych efektów szerokiego pasa i niestateczności ścianki w zakresie sprężysto - plastycznym. Wykorzystano normowy, sprężysto - plastyczny model stali z minimalnym, 
liniowym wzmocnieniem. W tym przypadku obliczenia numeryczne zostały podzielone na dwa etapy. Pierwszy z nich obejmował analizę Buckle w celu znalezienia kolejnych postaci utraty stateczności analizowanego modelu. Następnie, w drugim etapie wyniki z analizy Buckle zostały wczytane do modelu jako wstępne imperfekcje geometryczne. Wyniki zostały przeskalowane w taki sposób, by nie zostały przekroczone graniczne wartości imperfekcji zgodnie z normą PN-EN 1090-2. Drugi etap analizy został przeprowadzony przy wykorzystaniu procedury Static, Ricks dzięki której znaleziona została graniczna wartość obciążenia, po przekroczeniu której element ulegał utracie stateczności.

Przeprowadzone analizy wykazały, że siły wewnętrzne w belkach z szerokim pasem nie mogą być wyznaczane zgodnie z klasyczną teorią zginania, ponieważ wartości momentu zginającego oraz sił ścinających zależą od szerokości pasa. Wynika z tego, że w obliczeniach statycznych należy uwzględnić zredukowaną sztywność przekroju w odpowiednich przekrojach charakterystycznych na długości belki.

Przeprowadzone obliczenia numeryczne udowodniły również, że naprężenia w szerokich pasach nie mogą być wyznaczane zgodnie z klasyczną teorią belkową, ponieważ ich rozkład na szerokości pasa nie jest stały - maksymalne wartości naprężeń występują w przekroju nad środnikiem, a minimalne na krawędziach zewnętrznych pasa.

Warto również wspomnieć, że zapisy normowe dotyczących wpływu efektu „szerokiego pasa” nie prezentują w jaki sposób uwzględnić wpływ żeberek podporowych na rozkład naprężeń w pasach. Z uwagi na fakt, że w blachownicowych konstrukcjach stalowych żeberka podporowe są bardzo często stosowane, autorzy uznali za zasadne sprawdzenie jak zmieni się rozkład naprężeń w szerokim pasie po zastosowaniu żeberek. Z tego powodu w przeanalizowanych już modelach numerycznych dodano żeberka podporowe i porównano wyniki. Okazało się, że dodanie żeberek podporowych redukuje efekt „,szerokiego pasa”. Zastosowanie żeberek spowodowało redukcję naprężeń w przekroju w osi środnika na poziomie $45 \%$, a praktycznie zerową redukcję w przekroju na końcu pasa - co spowodowało zredukowanie nieliniowego rozkładu naprężeń w szerokim pasie. 